\title{
Anesthetic Management of a Patient with Pompe Disease: Our Experiment
}

\author{
Pompe Tanılı Bir Olguda Anestezi Uygulamamız
}

Ayşe Hande Arpacı, Ozan Kaan Venedik

Ankara University, Faculty of Dentistry, Department of Oral and Maxillofacial Surgery, Besevler, Ankara, Turkey

\begin{abstract}
Pompe disease is a fatal autosomal recessive glicogen storage disease presenting with hypertrophic cardiomyopathy, widespread myopathy and hypotonia. In this presentation, we aimed to present our anesthetic approach to 12 teeth extraction planned non-cooperative, 34-month-old patient who were being followed-up in an external center with Infantile Pompe Disease.
\end{abstract}

Key Words: Pompe disease, sedoanalgesia, monitorized anesthesia care
ÖZET

Pompe hastalığı, hipertrofik kardiyomyopati, hipotoni ve kas güçsüzlüğü ile seyreden otozomal resesif geçişli fatal bir glikojen depo hastalığıdır. Bu yazıda infantil pompe hastalığı tanısı ile dış merkezde takipli, 12 diş çekimi planlanan ancak kooperasyon kurulamadığından tarafımıza danışılan 34 aylık olguya anestezik yaklaşımımızı sunmak istedik.

Anahtar Sözcükler: Pompe hastalığı, sedoanaljezi, monitörize anestezi bakımı

Geliş Tarihi: 30.11 .2016

Kabul Tarihi: 15.03.2017

\section{INTRODUCTION}

Pompe disease is an autosomal recessive storage disease in which glycogen accumulates in tissues without hydrolysis due to the lack of lysosomal alphaglycosidase (acid maltase) enzyme. There are three types, infantile, with decreased enzyme activity, juvenile with absent enzyme activity and adult type. Infantile type usually results with death in the first two years due to hypertrophic cardiomyopathy, widespread myopathy, hypotonia, growth retardation and respiratory failure (1-4).

In this presentation, we aimed to present our anesthetic approach to 12 teeth extraction planned non-cooperative, 34-month-old patient who were being followed-up in an external center with Infantile Pompe Disease, who had hypertrophic cardiomyopathy, hypotonia, mental-motor retardation.

\section{CASE REPORT}

A 14-kg 34-month-old female patient with infantile Pompe disease who received enzyme treatment with 15 -day periods was consulted because of lack of cooperation during tooth extraction. In preoperative evaluation; The patient was diagnosed as having Mallampatia 3, with mouth opening reduced, macroglossia, wheezing, hepatosplenomegaly, hypotonia, she was planned to appropriate fasting period under appropriate anesthesia care (MAB). The patient was moved to operation room without premedication, EMLA ${ }^{\circledR}$ administered to left hand dorsum, monitorized by non-invasive means, peripheral Intravenous (IV) cannulation performed while nasal oxygen administered from $4 \mathrm{lt} / \mathrm{min}$. 
Infiltration anesthesia was performed with a mixture of Artikain $\mathrm{HCl}$-Epinefrin $\mathrm{HCl}\left(\right.$ Ultrakain $\left.^{\circledR}\right)+$ Lidocaine $\mathrm{HCl}\left(\right.$ Aritmal $\left.^{\circledR}\right)$ when Ramsey Sedation Scale (RSS) was detected to be 4, after IV application of $1.5 \mathrm{mg} \mathrm{kg-1}$ ketamine (Ketalar ${ }^{\circledR}$ ). During the $15 \mathrm{~min}$ procedure, $0.5 \mathrm{mg} \mathrm{kg}-1 \mathrm{IV}$ ketamine was administered to the patient as additional dose, at the end of the procedure patient was followedup for 10 minutes and moved to ward as hemodynamically stable, with RSS: 1.

\section{DISCUSSION}

Monitored anesthesia care (MAC) is defined as to monitor the patient by providing additional medication which anxiolytic, amnesic, analgesic and hypnotic to diagnose or to treat the patient for therapeutic intervention. The main purpose of MAC is ensuring patient comfort, removal of anxiety, pain control, hemodynamic stability, immolization of patient (5). With the combination of ketamine and infiltrational anesthetics, which we prefer because of the possibility of malignant hyperthermia and presence of hypertrophic cardiomyopathy. With ketamine's analgesic, hypnotic and amnestic effects, it doesnt surpress pharyngeal and laryngeal reflexes, does not cause cardiovascular and respiratory depression $(3,4,6)$ We believe that we have performed the procedure without side effects, without the need for additional anesthetic stabilization.

\section{Conflict of interest}

No conflict of interest was declared by the authors.

\section{REFERENCES}

1-Kishnani P, Howell RR. Pompe disease in infants and children. J Pediatrics 2004;144:35-43.

2-Raben N, Plotz P, Byrne BJ. Acid alpha-glucosidase deficiency (glycogenosis type II, Pompe disease). Curr Mol Med 2002;2:145-66. 3.

3-Tan D, Xu J, Yang Y, Gu M, Yu X. Postoperative acute respiratory failure caused by adultonset pompe disease. Clin Respir J. 2016 Jun 20. doi: 10.1111/crj.12514.

4-Al Atassi A, Al Zughaibi N, Naeim A, Al Basha A, Dimitriou V. Anesthesia Management In An Infant With Glycogen Storage Disease Type II (Pompe Disease). Middle East J Anaesthesiol. 2015;23:343-6.

5-Doğan O, Unver S, Tunçel YI, Keleş S, Süner ZC. Monitörize Anestezi Bakımında Deksmedetomidin ile Midazolam/Remifentanil Kombinasyonunun Karşılaştırılması. Türk Anest Rean Der Dergisi 2011; 39:292-301.

6- Arpaci AH, Isik B. Pediatric tooth extractions under sedoanalgesia. Pak J Med Sci. 2016;32:1291-5. 